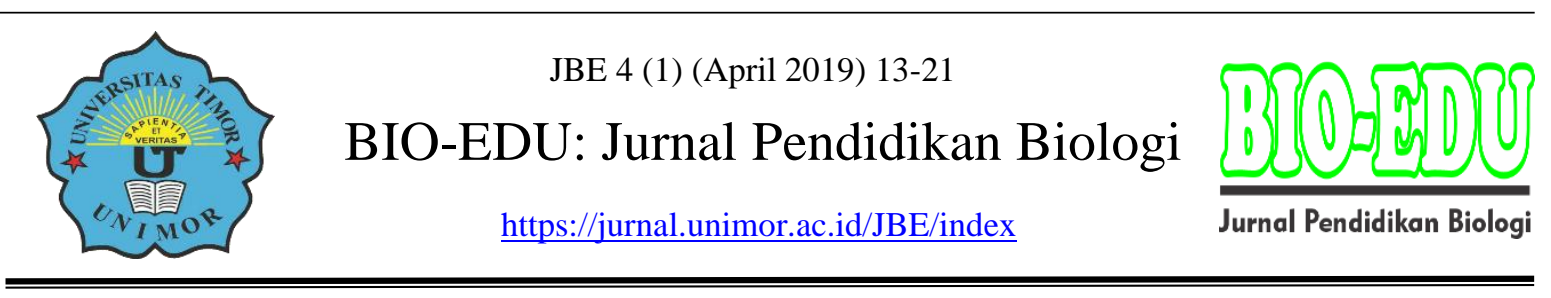

\title{
Analisis Potensi Think Pair Share dalam Pemberdayaan Keterampilan Metakognitif Siswa Laki-Laki dan Perempuan
}

\author{
Yunawati Sele \\ Program Studi Pendidikan Biologi, Universitas Timor \\ Email: yunawatisele@gmail.com
}

DOI: https://doi.org/10.32938/jbe.v4i1.342

\begin{abstract}
Abstrak
Think Pair Share (TPS) sebagai salah satu pembelajaran kooperatif telah dilaporkan berpotensi dalam pemberdayakan keterampilan metakognitif siswa. Namun laporan tersebut belum dikaitkan dengan adanya perbedaan gender. Tujuan penelitian ini adalah untuk menganalisis potensi TPS dalam pemberdayakan keterampilan metakognitif siswa laki-laki dan perempuan. Penelitian dilakukan pada semester gasal tahun ajaran 2015/2016. Subjek penelitian adalah siswa kelas X SMA Negeri 6 Malang. Instrumen yang digunakan adalah tes essay dan rubrik keterampilan metakognitif. Data yang diperoleh kemudian diuji normalitas dan homogenitasnya dan selanjutnya dianalisis dengan Anakova. Hasil analisis menunjukkan nilai signifikansi $p$ $=0,785$ atau > 0,05 yang berarti pembelajaran TPS memiliki potensi yang setara dalam memberdayakan keterampilan metakognitif siswa laki-laki dan siswa perempuan. Pelaksanaan pembelajaran TPS dapat memberikan kesempatan yang sama kesempatan yang sama kepada siswa laki-laki dan perempuan untuk terlibat dalam pembelajaran dan memberikan tuntutan yang sama untuk mendalami materi pembelajaran.
\end{abstract}

Kata kunci: Think Pair Share (TPS), keterampilan metakognitif, Siswa Laki-Laki Dan Perempuan

\begin{abstract}
Think Pair Share (TPS) as one of cooperative learning has been reported to be potentially used in the empowerment of students' metacognitive skills. But the report has not been linked to gender differences. The purpose of this study was to analyze the potential use of TPS in the empowerment of metacognitive skills of male and female students. This study was conducted in the first semester of 2015/2016 academic year. The research subjects were the students of class X of State Senior High School 6 Malang. The instruments used were an essay test and a rubric of metacognitive skills. The data obtained were then tested for the normality and homogeneity of the data, and further analyzed using Ancova test. The analysis showed a significance value of $p=0.785$ or $>0.05$ which means the TPS learning has equal potential in empowering metacognitive skills of male and female students. The implementation of TPS learning can provide equal opportunities for male and female students to be involved in learning and provide the same demands to explore learning material.
\end{abstract}

Keywords. Think Pair Share (TPS), metacognitive skills, male and female students

\section{PENDAHULUAN}

Think Pair Share (TPS) merupakan salah satu pembelajaran kooperatif yang banyak digunakan dalam pembelajaran. TPS yang pertama kali dikembangkan oleh Frank Lyman, 
memiliki tiga tahapan yang meliputi tahap think, tahap pair dan tahap share. Pada tahap think, guru memberikan pertanyaan terkait materi pembelajaran yang akan dipelajari. Diharapkan pertanyaan tersebut dapat merangsang rasa ingin tahu siswa, mendorong siswa untuk berpikir secara kritis dan mencoba menemukan jawaban dari pertanyaan tersebut. Pada tahap kedua yaitu tahap pair, siswa diberikan kesempatan untuk mendiskusikan hasil pemikiran mereka secara berpasangan sehingga terjadi proses saling tukar maupun penyatuan informasi terkait jawaban dari pertanyaan yang diberikan guru pada tahap think. Selanjutnya pada tahap share, siswa diberi kesempatan untuk berdiskusi dengan teman-teman sekelas sehingga siswa memperoleh informasi tambahan yang dapat dijadikan sebagai dasar untuk membandingkan dan mengetahui kekurangan jawaban yang mereka buat baik jawaban yang dibuat atas pemikiran sendiri, jawaban yang diperoleh setelah berdiskusi dengan pasangannya hingga jawaban hasil diskusi besar. Secara umum, aktivitas think yang mendorong siswa untuk berpikir secara individu, aktivitas pair yang mendorong siswa untuk melakukan diskusi dengan pasangannya dan aktivitas share yang mendorong siswa untuk mempresentasikan hasil diskusinya (Manarino-Leggett \& Solomon, 1989; McTighe dan Lyman, 1988; Azlina, 2010).

Sebagai model pembelajaran yang banyak digunakan dalam pembelajaran, berbagai penelitian telah dilakukan untuk mengungkap potensi pembelajaran TPS terhadap berbagai variabel hasil belajar siswa. Salah satu variabel yang diketahui dapat diberdayakan melalui penerapan model pembelajaran TPS adalah variabel keterampilan metakognitif siswa. Keterampilan metakognitif merupakan keterampilan siswa untuk merencanakan, memonitor dan mengevaluasi proses berpikirnya sehingga siswa mampu memilih strategi belajar yang tepat dan mampu belajar secara mandiri (Livingston, 1997; Dawson, 2008). Metakognitif dapat juga dimaknai sebagai kesadaran terhadap proses berpikir yang disertai dengan kemampuan untuk memantau dan mengatur berbagai proses kognitif sehingga proses belajar yang dilakukan semakin bermakna dan apa yang dipelajari dapat menjadi dasar dalam penentuan tindakan yang diambil untuk mengatasi permasalahan yang ditemui (Hennessey, 1999; Veenman et al, 2006). Keterampilan metakognitif yang baik akan memungkinkan terjadinya peningkatan kemampuan siswa untuk memahami materi pembelajaran, peningkatan kemampuan berkomunikasi, peningkatan perhatian siswa, peningkatan daya ingat siswa serta peningkatan kemampuan menyelesaikan masalah sehingga prestasi belajar siswa menjadi lebih baik (Howard, 2004; Coutinho, 2007).

Potensi model TPS dalam memberdayakan keterampilan metakognitif siswa telah dilaporkan oleh Muhfahroyin (2009) dan Amnah (2011). Dalam penerapannya, Think Pair Share juga diintegrasikan dengan model pembelajaran lain seperti PBMP, RQA dan STAD yang dilaporkan oleh Wahyu (2010), Bahtiar (2014), Vandalita (2014), dan Ermin (2012). Peneliti-peneliti tersebut melaporkan bahwa integrasi TPS dengan strategi-strategi tersebut terbukti semakin meningkatkan keterampilan metakognitif. Dari penelitian-penelitian tersebut dilaporan bahwa keefektifan penerapan TPS terkait dengan sintaksnya sendiri yang meliputi think, pair dan share. Melalui ketiga kegiatan tersebut siswa didorong untuk mengembangkan kemampuan belajar dan berpikirnya secara mandiri serta meningkatkan kemampuannya untuk berdiskusi dan membagi pemikirannya dengan teman lainnya.

Potensi TPS sebagaimana yang telah diuraikan tersebut merupakan potensi yang secara umum belum memperhatikan adanya perbedaan karakteristik siswa dalam kelas. 
Padahal diperlukan perhatian khusus terhadap beragamnya karakteristik siswa dalam pembelajaran. Salah satu karateristik yang nampak secara jelas dalam pembelajaran adalah perbedaan gender. Nasser (2016) menjelaskan bahwa guru perlu untuk menyadari adanya perbedaan karakteristik antara siswa laki-laki dan siswa perempuan sehingga guru mampu melaksanakan pembelajaran yang baik dan berhasil. Elliott (2000) menjelaskan bahwa perbedaan yang paling jelas terlihat adalah perbedaan fisik. Siswa laki-laki memiliki fisik yang lebih besar dan kuat dari siswa perempuan tetapi siswa perempuan cenderung untuk lebih cepat matang dibandingan siswa laki-laki. Dalam kemampuan spasial, siswa perempuan memiliki kemampuan yang lebih rendah. Namun dalam kemampuan verbal, siswa perempuan lebih unggul dibandingkan siswa laki-laki. Perbedaan gender juga dilaporkan dapat mempengaruhi motivasi siswa untuk berprestasi. Ada anggapan bahwa anak laki-laki lebih unggul dalam bidang sains dan matematika, sedangkan anak perempuan akan lebih unggul pada tugas-tugas yang lebih feminim seperti seni dan musik. Lebih lanjut, Pambudiono dkk (2013) menjelaskan bahwa perbedaan-perbedaan ditinjau dari perbedaan gender tersebut tampaknya berkaitan dengan kemampuan berpikir.

Berbagai fakta yang telah diuraikan sebelumnya menunjukkan bahwa perbedaan gender berpotensi untuk menyebabkan perbedaan perkembangan keterampilan termasuk perbedaan perkembangan keterampilan metakognitif siswa. Hal tersebut membuat pengkajian terhadap potensi suatu model pembelajaran termasuk model pembelajaran TPS tidak cukup hanya dilakukan secara umum, tetapi juga harus dilakukan untuk mengungkap potensi model pembelajaran dengan memperhatikan perbedaan gender. Karena itu, terkait dengan potensi model pembelajaran TPS, perlu dilakukan kajian untuk mengetahui ada tidaknya perbedaan peningkatan keterampilan metakognitif siswa laki-laki dan perempuan dalam pembelajaran biologi berbasis Think Pair Share.

\section{METODE}

Penelitian ini merupakan penelitian eksperimen semu dengan rancangan pretestpostest Nonequivalent Control Group Design. Rancangan penelitian dapat dilihat pada Tabel 1.

Populasi dalam penelitian ini adalah seluruh kelas X SMAN 6 Malang tahun pelajaran 2015/2016 yang berjumlah 3 kelas. Sampel yang diambil adalah kelas X-1 SMAN 6 Malang dengan jumlah siswa 38 orang, terdiri atas 17 siswa laki-laki dan 21 orang siswa perempuan. Penentuan sampel dilakukan secara acak. Data keterampilan metakognitif dikumpulkan menggunakan tes sebelum dan sesudah pembelajaran. Hasil tes keterampilan metakognitif dinilai dengan menggunakan rubrik keterampilan metakognitif yang dikembangkan oleh Corebima (2009). Data yang dikumpulkan selanjutnya dianalisis menggunakan anakova dengan bantuan program SPSS for windows.

\section{HASIL DAN PEMBAHASAN}

\section{Hasil}

Data keterampilan metakognitif siswa laki-laki dan perempuan yang mengikuti pembelajaran berbasis TPS dapat dilihat pada pada Gambar 1. 
Tabel 1. Rancangan Pretestt-Postest Nonequivalent Group Desain

\begin{tabular}{lccc}
\hline \multicolumn{1}{c}{ Kelompok } & Pre test & Perlakuan & Post test \\
\hline Siswa laki-laki & $\mathrm{O}_{1}$ & $\mathrm{X}$ & $\mathrm{O}_{2}$ \\
\hline Siswa perempuan & $\mathrm{O}_{3}$ & $\mathrm{X}$ & $\mathrm{O}_{4}$ \\
\hline
\end{tabular}

Keterangan : $\mathrm{O} 1=$ Skor pretest siswa laki-laki, $\mathrm{O} 2=$ Skor pos test siswa laki-laki, $\mathrm{O} 3=$ Skor pretest siswa perempuan, $\mathrm{O} 4=$ Skor pos test siswa perempuan, $\mathrm{X}=$ Strategi pembelajaran Think Pair Share

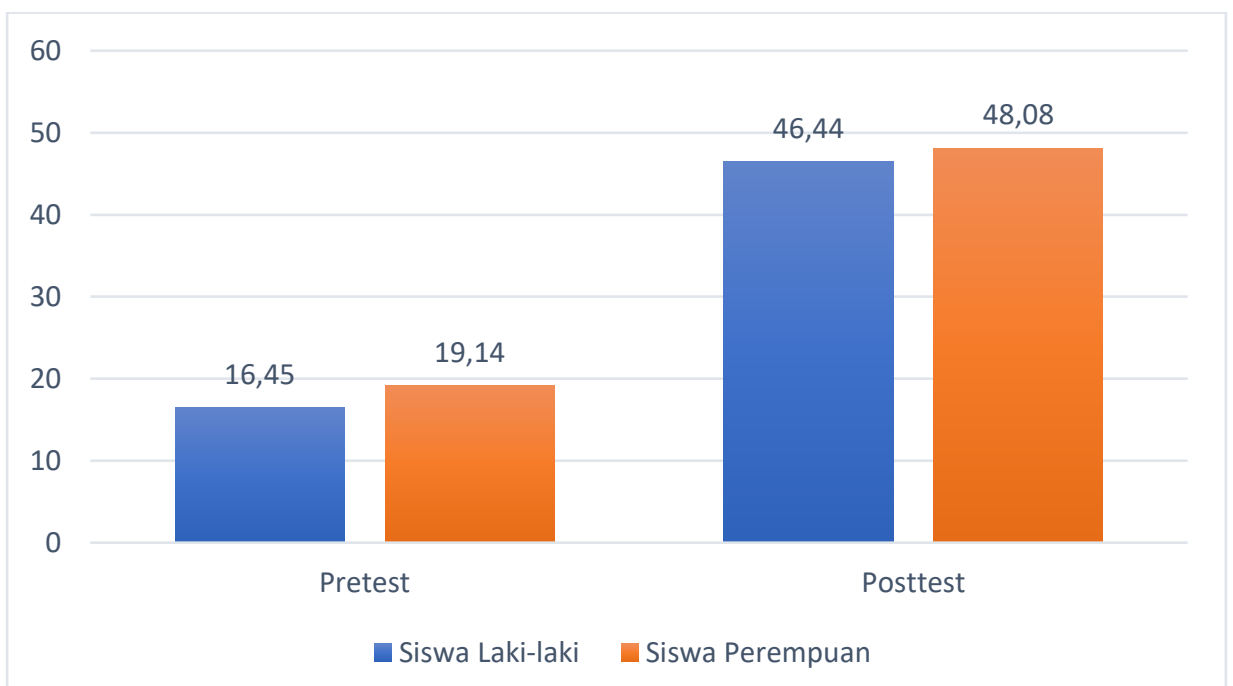

\section{Gambar 1. Profil Rata-rata Nilai Pretest dan Posttest Keterampilan Metakognitif}

Data pada Gambar 1 menunjukkan bahwa terjadi peningkatan keterampilan metakognitif siswa laki-laki dan siswa perempuan yang mengikuti pembelajaran dengan model pembelajaran TPS. Untuk siswa laki-laki, rerata nilai pretest keterampilan metakognitif adalah sebesar 16,45 sedangkan rerata nilai posttest sebesar 46,44. Nilai tersebut menunjukkan bahwa terjadi peningkatan sebesar 29.99 atau $182.31 \%$. Sedangkan untuk siswa perempuan, Rerata nilai pretest adalah sebesar 19,14 dan rerata nilai posttest sebesar 48.08. Nilai tersebut menunjukkan bahwa terjadi peningkatan sebesar 28.94 atau $151.20 \%$.

Data yang diperoleh kemudian dianalisis dengan anakova. Anakova merupakan salah satu jenis analisis parametrik yang dapat dilakukan apabila hasil uji prasyarat menunjukkan bahwa data yang diperoleh adalah data yang homogen dan terdistribusi normal. Karena itu, sebelum data dianalisis dengan anakova, terlebih dahulu dilakukan uji prasyarat berupa uji normalitas dan uji homogenitas data. Uji normalitas data menggunakan One-Sample Kolmogorov-Smirnov Test sedangkan uji homogenitas data dilakukan dengan Levene's Test of Equality of Error Variances. Berdasarkan hasil uji normalitas data keterampilan metakognitif diperoleh nilai $p$-value pretest $0,962<0,05$ yang berarti data terdistribusi normal, sedangkan $p$-value posttest $0,281>0,05$ yang berarti data terdistribusi normal. Selanjutnya berdasarkan hasil uji homogenitas data keterampilan metakognitif diperoleh 
nilai p-value pretest sebesar 0,097>0,05 yang berarti data homogen, sedangkan p-value postest sebesar 0,302 > 0,05 yang berarti data homogen.

Tabel 2. Ringkasan Hasil Uji Anakova Perbedaan Keterampilan Metakognitif Antar Gender

\begin{tabular}{|l|r|r|r|r|r|}
\hline Source & $\begin{array}{c}\text { Type III Sum } \\
\text { of Squares }\end{array}$ & Df & Mean Square & \multicolumn{1}{c|}{ F } & \multicolumn{1}{c|}{ Sig. } \\
\hline Corrected Model & 415.719 & 2 & 207.859 & 6.129 & .005 \\
Intercept & 1904.544 & 1 & 1904.544 & 56.159 & .000 \\
PretestketerampilanMet & 390.635 & 1 & 390.635 & 11.519 & .002 \\
akognitif & 2.575 & 1 & 2.575 & .076 & .785 \\
Gender & 1186.973 & 35 & 33.914 & & \\
Error & 86789.604 & 38 & & & \\
Total & 1602.692 & 37 & & & \\
Corrected Total & & & & \\
\hline
\end{tabular}

a. $\mathrm{R}$ Squared $=.259$ (Adjusted R Squared $=.217$ )

Karena hasil analisis menunjukkan bahwa data terdistribusi normal dan homogen maka analisis dilanjutkan dengan anaova. Hasil uji anakova disajikan pada Tabel 2. Berdasarkan data pada Tabel 2, bahwa dapat dilihat bahwa nilai $\mathrm{F}$ hitung dari perbedaan gender adalah sebesar 0.076 dengan nilai $\mathrm{p}=0,785$ atau yang lebih kecil dari alpha 0,05 . Hal tersebut menunjukkan bahwa tidak terdapat perbedaan keterampilan metakognitif antara siswa laki-laki dan siswa perempuan dalam pembelajaran biologi berbasis TPS.

\section{Pembahasan}

Hasil uji anakova menunjukkan bahwa dalam pembelajaran berbasis TPS, tidak terdapat perbedaan keterampilan metakognitif antara siswa laki-laki dan siswa perempuan. Hal tersebut menunjukkan bahwa model pembelajaran TPS memiliki potensi yang sama baik untuk memberdayaan keterampilan metakognitif siswa laki-laki maupun siswa perempuan. Potensi yang sama tersebut dapat disebabkan oleh karakteristik TPS sebagai salah satu model pembelajaran kooperatif. Melalui pembelajaran kooperatif, terjadi kolaborasi antar siswa baik siswa laki-laki maupun perempuan untuk belajar bersama dalam kelompok dengan mengintegrasikan kemampuan dan pengetahuan yang dimiliki masing-masing orang. Hal ini sejalan dengan pendapat Ekoningtyas (2013) yang menjelaskan bahwa adanya kerja sama antara siswa membuat siswa belajar satu sama lainnya untuk memastikan bahwa tiap orang dalam kelompok telah menguasai konsep-konsep yang sedang dibahas.

Dalam penelitian yang menerapkan model pembelajaran kooperatif ini, setiap siswa baik siswa laki-laki maupun siswa perempuan memiliki kesempatan yang sama untuk terlibat aktif dalam merencanakan, memonitor dan mengevaluasi kegiatan belajarnya sehingga terjadi pemberdayaan keterampilan metakognitif. Hal tersebut sesuai dengan Corebima (2006), yang menjelaskan bahwa pembelajaran kooperatif mendorong atau memberdayakan perkembangan pembelajaran metakognitif. Alasannya adalah karena dalam pembelajaran 17 I S e I e/JBE 4 ( 1) (April 2019 ) $13-21$ 
kooperatif terjadi siswa dalam setiap kelompok dimungkinkan untuk meningkatkan interaksi sosial dalam mengevaluasi kerja tiap anggota kelompok sebagai upaya meningkatan kualitas belajar masing-masing anggota.

Potensi model pembelajaran kooperatif dalam memberdayakan kemampuan siswa laki-laki maupun siswa perempuan telah dilaporkan oleh beberapa penelitian sebelumnya. Olson (2002) melalui penelitiannya yang mengkaji tentang perbedaan gender dan pengaruh pembelajaran kooperatif di tingkat perguruan tinggi melaporkan bahwa tidak ada perbedaan kemampuan antara siswa laki-laki dan perempuan yang mengikuti pembelajaran tersebut. Hal tersebut menunjukkan bahwa model pembelajaran kooperatif memiliki potensi yang sama pada siswa dengan gender yang berbeda. Hal serupa dilaporkan pula oleh Gupta et al (2014) yang dalam penelitiannya menerapkan model pembelajaran kooperatif tipe Student Teams Achievement Division (STAD) dan tipe Team Assisted Individualisation (TAI). Gupta et al (2014) melaporkan bahwa siswa laki-laki dan perempuan memiliki kemampuan yang tidak berbeda dalam pembelajaran kooperatif.

Selain potensi sebagai model pembelajaran kooperatif, fakta mengenai setaranya potensi TPS dalam memberdayakan keterampilan metakognitif siswa laki-laki dan perempuan tentu saja terkait pula dengan karakteristik TPS. Dalam penerapan TPS, seluruh siswa diberikan kesempatan untuk terlibat secara aktif dalam pembelajaran. Pada tahap think, masing-masing siswa diberikan tanggung jawab untuk berpikir secara individu. Pada tahap pair, secara berpasangan siswa mulai mendiskusikan jawaban yang sebelumnya telah mereka rumuskan. Sedangkan pada tahap share, seluruh siswa dalam terlibat dalam diskusi kelas untuk menentukan jawaban yang paling tepat terkait topik yang dipelajari. Gambaran pelaksanaan pembelajaran TPS menunjukkan bahwa baik siswa laki-laki maupun perempuan diberikan kesempatan yang sama untuk terlibat dalam pembelajaran dan tuntutan yang sama untuk mendalami materi pembelajaran.

Terkait dengan potensi TPS, Ermin (2012), Fauziah (2013) dan Kusuma (2014) melaporkan bahwa pelaksanaan TPS memberikan kontribusi pada peningkatan keterampilan metakognitif siswa. Melalui tahap-tahapnya, siswa diberikan kesempatan untuk belajar secara mandiri dan secara berpasangan sehingga aktivitas siwa dalam pembelajaran semakin meningkat. Dengan meningkatnya keterlibatan siswa maka kemampuan untuk merencanakan, memantau dan mengevaluasi proses belajar yang telah dilakukannya akan semakin meningkat pula. Hal tersebut sejalan juga dengan pendapat D'Avanzo (2003) yang menyatakan bahwa tahap pair dan share berpotensi dalam meningkatkan keterampilan metakognitif siswa melalui peningkatan pengetahuan metakognitif. Menurutnya, kedua tahapan tersebut memungkinkan siswa untuk mendiskusikan pendapatnya dengan siswa lain sehingga kesadaran akan pemikirannya sendiri akan semakin meningkat.

Secara statistik, data yang diperoleh menunjukkan bahwa siswa laki-laki dan siswa perempuan memiliki keterampilan metakognitif yang sama. Namun ketika dibandingkan besarnya peningkatan keterampilan metakognitif siswa maka dapat dilihat bahwa siswa lakilaki memiliki peningkatan yang lebih tinggi. Siswa laki-laki, mengalami peningkatan keterampilan metakognitif sebesar $182.31 \%$ sedangkan siswa perempuan mengalami peningkatan sebesar $151.20 \%$. Hal tersebut dapat disebabkan oleh adanya pola pemberian materi selama penelitian ini dilakukan. Materi yang dipelajari peneliti kepada siswa selama penelitian penerapan pembelajaran berbasis TPS ini adalah materi biologi kelas X semester 
ganjil yang meliputi materi keanekaragaman hayati, virus, bakteri dan protista. Selama pelaksanaan pembelajaran, siswa tidak hanya diminta untuk mempelajari materi dalam bentuk teks tetapi juga diberikan gambar-gambar terkait serta dilakukan pula praktikum di laboratorim. Karena itu, sedikit lebih tingginya peningkatan keterampilan metakognitif siswa laki-laki dibandingkan siswa perempuan menunjukkan bahwa pelaksanaan pembelajaran berbasis TPS yang dipadukan dengan penggunaan gambar terkait pembelajaran membuat kinerja siswa laki-laki sedikit lebih tinggi.

Fakta penelitian ini tentang lebih tingginya keterampilan metakognitif siswa laki-laki dapat dijelaskan bahwa siswa laki-laki cenderung memiliki kemampuan visual spasial yang lebih tinggi dari siswa perempuan (Nasser, 2016; Suprapto et al, 2018). Kemampuan visual adalah kemampuan untuk memahami, memproses, dan berpikir dalam bentuk visual dan menerjemahkannya. Selain itu, diketahui dalam bidang sains siswa laki-laki juga lebih unggul dibandingkan dengan siswa perempuan (Ma, 2007; Suprapto et al, 2018).

\section{KESIMPULAN DAN SARAN}

\section{Kesimpulan}

Berdasarkan hasil analisis data dan pembahasan dapat disimpulkan bahwa pembelajaran berbasis TPS mempunyai potensi yang setara dalam meningkatan keterampilan metakognitif baik bagi siswa laki-laki maupun siswa perempuan

\section{Saran}

Perlu penelitian lebih lanjut untuk melihat potensi pembelajaran berbasis TPS dalam memberdayakan keterampilan metakognitif siswa pada jenjang pendidikan yang berbeda.

\section{DAFTAR RUJUKAN}

Amnah, S. (2011). Pembelajaran Think-Pair-Share, Keterampilan Metakognitif, Dan Hasil Belajar Kognitif Siswa SMA. Pekanbaru: FKIP Universitas Islam Riau

Azlina, N.A.N. (2010). CETLs: Supporting Collaborative Activities Among Students and Teachers Through the Use of Think Pair-Share Techniques. International Journal of Computer Science Issues, Vol. 7, Issue 5, September 201018 ISSN 1694-0814

Bahtiar. (2014). Pengaruh Pembelajaran Think Pair Share (TPS) dan Reading Questioning Answering (RQA) terhadap Sikap Sosial, Keterampilan Metakognisi dan Penguasaan Konsep Biologi untuk Pendidikan Multietnis pada Siswa SMA di Ternate. Disertasi tidak diterbitkan. Malang: Pascasarjana Universitas Negeri Malang

Corebima, A.D. (2006). Berdayakan Kemampuan Berpikir Dan Kemampuan Metakognitif Selama Pembelajaran. Makalah disampaikan pada Pelatihan Strategi Metakognitif pada Pembelajaran Biologi untuk Guru-guru Biologi SMA di Kota Palangkaraya, 23 Agustus 2006

Corebima, A.D. (2009). Metacognitive Skills Measurement Integrated in Achievement Test. Makalah disajikan dalam Third International Conference on Science and Mathematics Education (CosMEd). Malaysia, 10-12 November 
Coutinho, S. A. (2007). The Relationship Between Goals Metacognition and Academic Success. Retrieved from http://www.educatejournal.org/index.php/educate/article/view/116/134

D’Avanzo, C.A. (2003). Application of Research on Learning to College Teaching: Ecological Examples. BioScience,53, 1121-1128.doi: 10.1641/00063568(2003)053[1121:AOROLT]2.0.CO;2

Dawson, T .L. (2008). Metacognition and Learning in Adulthood. Retrieved from https://dts.lectica.org/PDF/Metacognition.pdf

Ekoningtyas. M. (2013). Pengaruh Pembelajaran Think-Pair-Share dipadu Pola Pemberdayaan Berpikir melalui Pertanyaan terhadap Keterampilan Metakognitif, Berpikir Kreatif, Pemahaman Konsep IPA dan Retensinya serta Sikap Sosial Siswa. Jurnal Pendidikan Sains, Volume 1, Nomor 4, Desember 2013, Halaman 332-342

Elliot, S. N., Kratochwill, T. R., Cook, J. L. \& Travers, J. F. (2000). Educational Psycology: Effective Teaching, Effective Learning, Third Edition. United States of America: McGraw-Hill Companies, Inc.

Ermin. (2012). Pengaruh Pembelajaran Kooperatif Student Team Achivement Divisions (STAD) dipadu Think Pair Share (TPS) dan Kemampuan Akademik terhadap Keterampilan Metakognisi, Kemampuan Berpikir Kritis, dan Hasil Belajar Kognitif Biologi pada Siswa Kelas VII SMP Negeri 4 Kota Ternate. Tesis tidak diterbitkan. Malang: Pascasarjana Universitas Negeri Malang.

Fauziyah, D. R. (2013). Hubungan Keterampilan Metakognitif terhadap Hasil Belajar Biologi dan Retensi Siswa Kelas X dengan Penerapan Strategi Pembelajaran Think Pair Share di SMA Negeri 6 Malang. Skripsi. Malang: Program Studi Pendidikan Biologi Universitas Negeri Malang.

Gupta, M. Jain, M., \& Pasrija, P. (2014). Gender Related Effects of Co-Operative Learning Strategies (STAD And TAI) on Mathematics Achievement. Issues and Ideas in Education Vol. 2, No. 1 March 2014. pp. 53-68

Hennessey, M. G. (1999). Probing the Dimensions of Metacognition: Implications for Conceptual Change Teaching-learning. Paper presented at the Annual Meeting of the National Association for Research in Science Teaching, Boston, MA, March 28-31, 1999.

Howard, J.B. (2004). Metacognitive Inquiry. School of Education Elon University. Retrieved from http://org.elon.edu/t2project/pdf_docs/sp_metacognitive.pdf

Kusuma, A.S.H.M. (2014). Pengaruh Strategi Pembelajaran Reading, Questioning and Answering (RQA), Think Pair Share (TPS), RQA dipadu TPS dan Perbedaan Gender terhadap Keterampilan Bertanya, Kesadaran Metakognitif, Keterampilan Metakognitif, Pembentukan Karakter dan Hasil Belajar Biologi Siswa Kelas VIII SMP Negeri Kota Malang. Tesis tidak diterbitkan. Malang: Pascasarjana. Universitas Negeri Malang.

20|Sele/JBE 4(1) (April 2019) $13-21$ 
Livingston, J.A. (1997). Metacognition: An Overview. Retrieved from http://gse.buffalo.edu/fas/shuell/cep564/metacog.htm

Ma, X. (2007). Gender Differences in Learning Outcomes. Education for All Global Monitoring Report 2008 Education for All by 2015: will we make it?. Retrieved from http://www.unesco.org/new/fileadmin/MULTIMEDIA/HQ/ED/pdf/gmr2013thematic-notev2.pdf.pdf

Manarino-Leggett, P., \& Salomon, P. A. (1989). Cooperation vs. Competition: Techniques for Keeping Your Classroom Alive but Not Endangered. Paper presented at the Annual Meeting of the International Reading Association (34th, New Orleans, LA, April 30-May 4, 1989).

McTighe, J. \& Lyman, F.T. (1988). Cueing Thinking in the classroom: The Promise of Theory-Embedded Tools. Educational Leadership, 45(7), 18-24.

Muhfahroyin. (2009). Pengaruh Strategi Pembelajaran Integrasi STAD dan TPS dan Kemampuan Akademik terhadap Hasil Belajar Kognitif Biologi, Kemampuan Berpikir Kritis, dan Keterampilan Proses Siswa SMA di Kota Metro. Disertasi tidak diterbitkan. Malang: Pascasarjana Universitas Negeri Malang

Nasser, A. (2016). The Difference Between Girls and Boys in Learning. Retrieved from https://www.researchgate.net/publication/311855897

Olson, V. E. (2002). Gender Differences and the Effects of Cooperative Learning in College Level Mathematics. Thesis. Perth: Curtin University of Technology

Pambudiono, A., Zubaidah, S. \& Mahanal, S. (2013). Perbedaan Kemampuan Berpikir Dan Hasil Belajar Biologi Siswa Kelas X SMA Negeri 7 Malang Berdasarkan Jender Dengan Penerapan Strategi Jigsaw. Retrieved from https://www.researchgate.net/publication/325809484

Suprapto., Zubaidah. S., \& Corebima. A. D. (2018). Pengaruh Gender terhadap Keterampilan Berpikir Kreatif Siswa pada Pembelajaran Biologi. Jurnal Pendidikan. Teori, Penelitian dan Pengembangan. Vol. 3, No. 3, Bln Maret, Thn 2018, Hal 325-329

Vandalita, M.M.R. (2012). Pengaruh Strategi Pembelajaran Berpola Pemberdayaan Berpikir Melalui Pertanyaan (PBMP) dengan Think Pair Share (TPS) terhadap Sikap Sosial, Keterampilan Berpikir Kritis, Pemahaman Konsep, dan Retensi Biologi Siswa Multietnis di SMP Kota Samarinda. Disertasi tidak diterbitkan. Malang: Pascasarjana Universitas Negeri Malang

Veenman, M. V., \& Afferbach,P. (2006). Metacognition and Learning: Conceptual and Methodological Considerations. Metacognition Learning, 1: 3-14, doi 10.1007/s11409-006-6893-0

Wahyu, T.A. 2010. Pengaruh Strategi Pembelajaran TPS (Think Pair Share) dan TPS (Think Pair Share) yang dipadu PBMP (Pemberdayaan Berpikir Melalui Pertanyaan) terhadap Keterampilan Metakognitif, Kemampuan Berpikir Kritis dan Hasil Belajar Kognitif Siswa Kelas VIII SMPN 2 Singosari. Skripsi tidak diterbitkan. Malang: Program Studi Pendidikan Biologi. Universitas Negeri Malang.

21|Sele/JBE 4(1) (April 2019 ) 13-21 